Vol. 3, No. 1 | January - June 2019

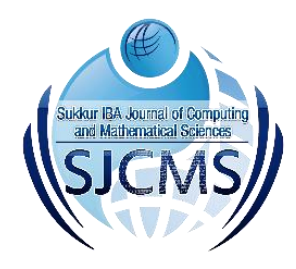

\title{
A Priority Based Intelligent Transportation (IT) Assistance Model for Victims in Incident Environment Using Drone and eCall Technology
}

\author{
Sana Ullah ${ }^{1}$
}

\begin{abstract}
:
With the advancement in information technology (IT), transportation sector has been evolved remarkably. Numerous technologies have been deployed to assist and manage transportation systems in emergency and incident situations. Assisting the serious injured in road accidents is extremely important on time and a little delay in medical assistance leads to huge lives loss. In this connection, a model "A Priority Based Intelligent Transportation (IT) Assistance Model for Victims in Emergency/Incident Environment Using Drone and eCall Technology" has been proposed which assist victims/accident injured on priority basis. The main breakthroughs of the proposed model are inclusive of diminished/minimized lives losses, saving time, speed up rescuing process; maximize efficiency, improving the transport results like traffic resilience, travel reliability, environment protection and road safety. For the validation of the proposed research model, a quantitative research approach (Survey) has been utilized. The expert opinions are gathered from field experts in different rounds through questionnaire. The hypotheses are assessed based on chi-squared test statistical method.
\end{abstract}

Keywords: Intelligent Transportation System (ITS), Artificial Intelligence, Transportation, IT, Drone Technology, Mobile Technology, Incident environment, Emergency environment, Intelligent Transportation System (ITS), Incident detection

\section{Introduction}

With the rapid increase in world population, road traffic is increasing rapidly. It ultimately boosts up business activities and as well vehicles and cars for transportation. City planning is an important phase to plan transportation routes well to decrease transportation issues. Proper transportation systems management can lead to attract foreigner investors, economy, social well-being and nation progress. Furthermore, the integration of technology plays a vital role in enhancing transportation [1]. Transportation is a legal sector which involves carrying of things. Due to more congestion in transportation, diverse issues have been faced which are inclusive of injuries in crash, high accidents rate, air pollution, traffic congestion. The integration of virtual technologies has

${ }^{1}$ University of Electronic Science and Technology of China (UESTC). Corresponding Email: Sanaullah.cs@fuuast.edu.pk diminished such faced problem up to some limit. The technological integrated transportation system is termed as Intelligent Transport System (ITS) [2].

The deployment of different technological systems in Intelligent Transport System (ITS) plays an important role in decreasing different traffic faced problems. The integrated information systems are including Traveler Information Systems, Regional Multimodal Systems, Electronic Toll Collection (ETC), Emergency Management Systems, Incident Management Systems, Transit Management Systems (ITS), Freight and Intelligent Transportation Management Systems. The integrated technologies play a vital role in control methods, policies and infrastructure. The Emergency Vehicle Preemption 
Sana Ullah(et.al), A Priority Based Intelligent Transportation (IT) Assistance Model for Victims in Emergency/Incident Environment Using Drone and eCall

(EVP), Transit Signal (ITS), Vehicle Data Collection (VDC) and Intelligent Transportation System (TMS) have significant role in reducing risks. Different technologies which can be integrated in Intelligent Transport System (ITS) are listed in Table-1 [3]. Different enabled technologies have been integrated in ITSs which is shown in the Table I.

Table I: ITS Enabled Technologies

\begin{tabular}{|c|c|c|}
\hline S. No & Technologies & Systems \\
\hline 1 & Communication & Wireless (Cellular or Wide Area) Wire line (Coaxial or Fiber Optic) \\
\hline 2 & Data Storage and Processing & $\begin{array}{c}\text { Compact Disc, Magnetic storage, Media Magnetic stripe cards, hard disks } \\
\text { and data cartridges, smart cards. }\end{array}$ \\
\hline 3 & Database Management Systems & Data Warehousing, Expert Systems, \\
\hline 4 & Information Display & Cathode ray Tubes (CRTS), LCDs, Variable message sign. \\
\hline 5 & Location & Dead reckoning, Map matching, GPS, Beacon based Vehicle Location \\
\hline 6 & Sensors & $\begin{array}{c}\text { Inductive Loops, Infrared Beams, Microwave (RADAR), LIDAR, Vision- } \\
\text { based Sensors, Acoustic scanning Laser }\end{array}$ \\
\hline 7 & Actuator & \begin{tabular}{c} 
Gates and Displays \\
\hline
\end{tabular} \\
\hline
\end{tabular}

\subsection{Major categories of Intelligent Transportation System (ITS)}

The intelligent transportation system (ITS) is sub divided in six categories [4].

I. Advanced Traffic Management Systems (ATMS): The main aim of ATMS is to reduce traffic jam and as well to enhance quality of traffic services. It operates with ramp meter timing schedules, network signals, variable message signs, roadway loop detectors and video. There are around three elements of ATMS which include collection team members, support systems and real time traffic control systems.

II. Advance Travelers Information Systems (ATIS): In this, real time traffic information is sent to travel.

III. Commercial Vehicles Operation (CVO): It integrates diverse ITS technologies to improve efficiency and safety of commercial vehicles.

IV. Advanced Public Traffic Transmissions (APTS): It integrates different electronic technologies to improve efficiency and operations of large vehicles such as trains and buses.

V. Advanced Vehicles Control Systems (AVCS): It utilizes control systems, computers and sensors technologies to generate alerts for drivers in any unconditional situations. The core aim is boosting safety decreasing congestion on road [5].

VI. Advanced Rural Transports Systems (ARTS): Its main purpose is to handle problems of rural areas traffic. Road infrastructures differ by different attributes such as few alternative routes, mix of users, few navigational signs, curves, blind corners and steep grades [6].

\subsection{Incident Management Systems}

In Intelligent Transport System (ITS), incident management systems play an important role. It is best utilized whenever different incidents happened. It is helpful in incidents such as 9/11 attacks, 2018 Sichuan earthquake and SARS epidemic. The disaster assistive teams, ambulances and vehicles can track the suitable safe route to the affected regions. The World Health Organization (WHO) reported that in Europe accidents and injuries were around thirty-one thousand per year. The deaths due to transportation incidents will become fifth foremost reason by 2030 [15]. The integration of technologies in incident management areas is like prototype recognition, calculation, storage, data gathering make incident information exploration, 
processing more efficient [7]. Incident management system is further divided into sub systems which are traffic management, incident detection, emergency response management and roadway incident management system. Diverse systems and models have been proposed for managing incident management which are inclusive of cyber physical system (CPS), critical incident management (CIMS) and many more. The details of systems are shown in Table II and Table III shows Regional Multimodal and Traveler Information Systems/ Information Management systems [8-11]

Table II: Incident Management Systems

\begin{tabular}{|c|c|c|c|}
\hline Author (s) & Title & Problem & Solution \\
\hline $\begin{array}{c}\text { Jin Ki Kim } \\
\text { November } \\
2007\end{array}$ & $\begin{array}{c}\text { Efficiency of critical incident } \\
\text { management systems: Instrument } \\
\text { development and validation }\end{array}$ & $\begin{array}{c}\text { A poor assessment of CIMS } \\
\text { efficiency }\end{array}$ & CIMS efficiency model \\
\hline $\begin{array}{c}\text { Yaodong } \\
\text { Wang } \\
\text { November } \\
2012\end{array}$ & $\begin{array}{c}\text { Perceptual control architecture for } \\
\text { cyber-physical systems in traffic } \\
\text { incident management }\end{array}$ & $\begin{array}{c}\text { Problem of unified modeling for } \\
\text { incompatible approaches of } \\
\text { Cyber-Physical Systems (CPSs) }\end{array}$ & $\begin{array}{c}\text { Perceptual Control Architecture of } \\
\text { CPSs }\end{array}$ \\
\hline $\begin{array}{c}\text { S. Akhtar } \\
\text { Ali } \\
\begin{array}{c}\text { ShahJune } \\
2008\end{array}\end{array}$ & $\begin{array}{c}\text { System architecture of a decision } \\
\text { support system for freeway incident } \\
\text { management in Republic of Korea }\end{array}$ & $\begin{array}{c}\text { Inefficient freeway network in } \\
\text { the post-incident scenario }\end{array}$ & $\begin{array}{c}\text { FIAS - Freeway Incident Analysis } \\
\text { System }\end{array}$ \\
\hline $\begin{array}{c}\text { Choi, E.H.C. } \\
\text { March 2007 }\end{array}$ & $\begin{array}{c}\text { Multimodal user interface for traffic } \\
\text { incident management in control } \\
\text { room }\end{array}$ & Collection of critical data & $\begin{array}{c}\text { Advanced MMUI systems for } \\
\text { emergency management }\end{array}$ \\
\hline
\end{tabular}

Table III: Traveler Information Management \& Regional Multimodal systems

\begin{tabular}{|c|c|c|c|}
\hline Author (s) & Title & Problem & Solution \\
\hline $\begin{array}{c}\text { Natvig, M.K. } \\
\text { December 2010 }\end{array}$ & $\begin{array}{c}\text { Flexible organization of } \\
\text { multimodal travel information } \\
\text { services }\end{array}$ & $\begin{array}{c}\text { Inefficient and flexible } \\
\text { establishment and provision of } \\
\text { new and improved travel } \\
\text { information services }\end{array}$ & $\begin{array}{c}\text { Generic and multimodal ITS } \\
\text { framework }\end{array}$ \\
\hline Jianwei Zhang 2011 & $\begin{array}{c}\text { A multimodal transport } \\
\text { network model for advanced } \\
\text { traveler information systems }\end{array}$ & $\begin{array}{c}\text { Delay time for data reading and } \\
\text { compiling }\end{array}$ & $\begin{array}{c}\text { Generic multimodal transport } \\
\text { network model for ATIS } \\
\text { applications }\end{array}$ \\
\hline $\begin{array}{c}\text { Zhong-Ren Peng } \\
\text { September 1997 }\end{array}$ & $\begin{array}{c}\text { A methodology for design of a } \\
\text { GIS-based automatic transit } \\
\text { traveler information system }\end{array}$ & $\begin{array}{c}\text { Inefficient system of trip planning } \\
\text { for transit customers }\end{array}$ & $\begin{array}{c}\text { GIS)-based automatic transit } \\
\text { traveler information system } \\
\text { (ATTIS) }\end{array}$ \\
\hline Gerhard & Use of ITS Technologies for \\
Mchilka 2012 & Operimodal Transport & $\begin{array}{c}\text { Deficiency in transport planning } \\
\text { and management processes }\end{array}$ & $\begin{array}{c}\text { Next generation of multimodal } \\
\text { transport management and } \\
\text { information systems }\end{array}$ \\
& Information Services (RIS) & & \\
\hline
\end{tabular}




\subsection{Emergency Management Systems}

The emergency management system is the discipline deals with risk avoidance and risks [12]. It is mostly related to natural hazards which are danger for human life such as mass movement, volcanic, geological, seismic, meteorological and hydrological. The emergency management system emergency management system monitors and the collected information is provided to transportation system for dealing with emergencies on priority. Incident management techniques and models changed with time, and new technological systems are proposed like optimal models, prototype models, Multi-commodity stochastic humanitarian inventory management model (MCSHIC) which are utilized for efficiency, decision support and security purpose. The Table IV shows emergency management systems, while the Table V shows Vehicular Communication application and characteristics [13-16].

Table IV: Summarized literature of Emergency Management System

\begin{tabular}{|l|l|l|l|}
\hline Author (s) & Title & Problem & Solution \\
\hline $\begin{array}{l}\text { James H. } \\
\text { Lamberta January }\end{array}$ & $\begin{array}{l}\text { Understanding and managing } \\
\text { disaster evacuation on a } \\
\text { transportation network }\end{array}$ & $\begin{array}{l}\text { Harmful performance of the } \\
\text { region's transportation system }\end{array}$ & $\begin{array}{l}\text { Analyze transportation system } \\
\text { demand and system and its } \\
\text { performance for emergency } \\
\text { management }\end{array}$ \\
\hline $\begin{array}{l}\text { Eren Erman } \\
\text { Ozguven April } \\
2013\end{array}$ & $\begin{array}{l}\text { A secure and efficient inventory } \\
\text { management system for } \\
\text { disasters }\end{array}$ & $\begin{array}{l}\text { Inefficient usage and } \\
\text { distribution of emergency } \\
\text { supplies }\end{array}$ & $\begin{array}{l}\text { Multi-commodity stochastic } \\
\text { humanitarian inventory } \\
\text { management model (MC-SHIC) }\end{array}$ \\
\hline $\begin{array}{l}\text { S.W. Yoona, } \\
\text { December 2008 }\end{array}$ & $\begin{array}{l}\text { Transportation security decision } \\
\text { support system for emergency } \\
\text { response: A training prototype }\end{array}$ & $\begin{array}{l}\text { Challenging Task of decision } \\
\text { making in emergencies }\end{array}$ & The emergency training prototype \\
\hline $\begin{array}{l}\text { Deng Chunlin } \\
2012\end{array}$ & $\begin{array}{l}\text { Sample Average Approximation } \\
\text { Method for Chance Constrained } \\
\text { Stochastic Programming in } \\
\text { Transportation Model of } \\
\text { Emergency Management }\end{array}$ & $\begin{array}{l}\text { Problem of the chance } \\
\text { constrained stochastic } \\
\text { programming }\end{array}$ & $\begin{array}{l}\text { Optimal model for the } \\
\text { transportation of emergency } \\
\text { resource }\end{array}$ \\
\hline
\end{tabular}




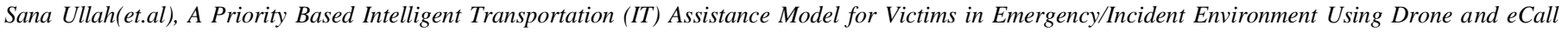

Table V: Vehicular Communication application and characteristics

\begin{tabular}{|c|c|c|c|c|c|c|}
\hline $\begin{array}{l}\text { S. } \\
\text { No }\end{array}$ & Application Name & Communication & Messaging Type & $\begin{array}{l}\text { Message } \\
\text { Period }\end{array}$ & Latency & Other Requirements \\
\hline 1 & $\begin{array}{c}\text { Emergency Electronic } \\
\text { Break Lights }\end{array}$ & Ad hoc V2V & $\begin{array}{c}\text { Event-triggered, } \\
\text { time-limited } \\
\text { broadcast }\end{array}$ & $100 \mathrm{~ms}$ & $100 \mathrm{~ms}$ & $\begin{array}{l}\text { Range:300 m, high } \\
\text { priority }\end{array}$ \\
\hline 2 & $\begin{array}{l}\text { Intersection Collision } \\
\text { Warning }\end{array}$ & $\begin{array}{c}\text { Ad hoc, } \\
\text { infrastructure } \\
\text { V2V,V2I }\end{array}$ & $\begin{array}{l}\text { Periodic permanent } \\
\text { broadcast }\end{array}$ & $100 \mathrm{~ms}$ & $100 \mathrm{~ms}$ & $\begin{array}{l}\text { Accurate positioning } \\
\text { on a digital map, high } \\
\text { priority }\end{array}$ \\
\hline 3 & $\begin{array}{l}\text { Intersection Collision } \\
\text { Warning }\end{array}$ & $\begin{array}{c}\text { Ad hoc, } \\
\text { infrastructure } \\
\text { V2V,V2I }\end{array}$ & $\begin{array}{c}\text { Event-Triggered } \\
\text { time-limited Geo } \\
\text { Cast } \\
\end{array}$ & $100 \mathrm{~ms}$ & $100 \mathrm{~ms}$ & High priority \\
\hline 4 & $\begin{array}{l}\text { Hazardous Location } \\
\text { Warning }\end{array}$ & $\begin{array}{c}\text { Ad hoc, } \\
\text { infrastructure } \\
\text { V2V,V2I }\end{array}$ & $\begin{array}{c}\text { Event-Triggered } \\
\text { time-limited Geo } \\
\text { Cast }\end{array}$ & $100 \mathrm{~ms}$ & $100 \mathrm{~ms}$ & High priority \\
\hline 5 & $\begin{array}{c}\text { Traffic Signal } \\
\text { Violation Warning }\end{array}$ & $\begin{array}{c}\text { Ad hoc, } \\
\text { infrastructure I2V }\end{array}$ & $\begin{array}{c}\text { Event-Triggered } \\
\text { time-limited } \\
\text { broadcast }\end{array}$ & $100 \mathrm{~ms}$ & $100 \mathrm{~ms}$ & $\begin{array}{c}\text { Range: } 250 \mathrm{~m}, \text { High } \\
\text { priority }\end{array}$ \\
\hline 6 & Pre-Crash Sensing & Ad hoc V2V & $\begin{array}{c}\text { Periodic broadcast, } \\
\text { unicast }\end{array}$ & $100 \mathrm{~ms}$ & $50 \mathrm{~ms}$ & $\begin{array}{c}\text { Range: } 50 \mathrm{~m} \text {, } \\
\text { high/mid priority } \\
\text { for beaconing/unicast }\end{array}$ \\
\hline 7 & $\begin{array}{c}\text { Lane Changing } \\
\text { Warning }\end{array}$ & Ad hoc V2V & Periodic broadcast & $100 \mathrm{~ms}$ & $100 \mathrm{~ms}$ & $\begin{array}{c}\text { Relative positioning } \\
\text { accuracy: < } \\
2 \mathrm{~m} ; \text { range }: 150 \mathrm{~m} \\
\end{array}$ \\
\hline 8 & $\begin{array}{l}\text { Cooperative forward } \\
\text { collision warning }\end{array}$ & Ad Hoc V2V & $\begin{array}{c}\text { Periodic, event- } \\
\text { triggered broadcast, } \\
\text { unicast }\end{array}$ & $100 \mathrm{~ms}$ & $100 \mathrm{~ms}$ & $\begin{array}{c}\text { Relative } \\
\text { positioningaccuracy: } \\
\text { <1m; range: } 150 \mathrm{~m}\end{array}$ \\
\hline 9 & $\begin{array}{c}\text { Intersection } \\
\text { Management }\end{array}$ & $\begin{array}{c}\text { Infrastructure, ad hoc } \\
\text { V2I,V2V }\end{array}$ & $\begin{array}{c}\text { Periodic broadcast, } \\
\text { unicast }\end{array}$ & $1000 \mathrm{~ms}$ & $500 \mathrm{~ms}$ & $\begin{array}{l}\text { Positioning accuracy: } \\
<5 \mathrm{~m}\end{array}$ \\
\hline 10 & $\begin{array}{l}\text { Limited Access and } \\
\text { Detour Warning }\end{array}$ & $\begin{array}{l}\text { Infrastructure, I2V, } \\
\text { other } \\
\text { broadcast network }\end{array}$ & Periodic Broadcast & $100 \mathrm{~ms}$ & $500 \mathrm{~ms}$ & Mid/Low priority \\
\hline 11 & $\begin{array}{c}\text { Cooperative Adaptive } \\
\text { cruise control }\end{array}$ & Ad hoc V2V & Unicast Broadcast & $500 \mathrm{~ms}$ & $100 \mathrm{~ms}$ & Mid priority \\
\hline 12 & Electronic Toll Collect & $\begin{array}{l}\text { Infrastructure, ad hoc } \\
\text { V2I, Cellular }\end{array}$ & $\begin{array}{c}\text { Periodic } \\
\text { broadcast,unicast }\end{array}$ & $1000 \mathrm{~ms}$ & $200 \mathrm{~ms}$ & CEN DSRC \\
\hline 13 & $\begin{array}{l}\text { Remote Diagnosis/ } \\
\text { JIT Repair Warning }\end{array}$ & $\begin{array}{l}\text { Infrastructure, ad hoc } \\
\text { V2I,V2V, Cellular }\end{array}$ & $\begin{array}{l}\text { Unicast, broadcast, } \\
\text { event-triggered }\end{array}$ & N/A & $500 \mathrm{~ms}$ & $\begin{array}{c}\text { Internet access } \\
\text { Service availability }\end{array}$ \\
\hline 14 & Media Download & $\begin{array}{l}\text { Infrastructure; } \\
\text { cellular, other } \\
\text { broadcast network }\end{array}$ & $\begin{array}{l}\text { Unicast, broadcast, } \\
\text { on -demand }\end{array}$ & N/A & $500 \mathrm{~ms}$ & $\begin{array}{c}\text { Internet access } \\
\text { Digital rights } \\
\text { management }\end{array}$ \\
\hline 15 & $\begin{array}{c}\text { Map Download/ } \\
\text { update }\end{array}$ & $\begin{array}{l}\text { Infrastructure, ad hoc } \\
\text { V2I,V2V, cellular, } \\
\text { other broadcast } \\
\text { network }\end{array}$ & $\begin{array}{l}\text { Unicast, broadcast, } \\
\text { on -demand }\end{array}$ & $1000 \mathrm{~ms}$ & $500 \mathrm{~ms}$ & $\begin{array}{c}\text { Internet access } \\
\text { Digital rights } \\
\text { management Services } \\
\text { availability }\end{array}$ \\
\hline 16 & $\begin{array}{c}\text { Ecological Drive } \\
\text { assistance }\end{array}$ & $\begin{array}{c}\text { Infrastructure, ad hoc } \\
\text { V2I,V2V, cellular }\end{array}$ & $\begin{array}{c}\text { Unicast, broadcast, } \\
\text { on-demand }\end{array}$ & $1000 \mathrm{~ms}$ & $500 \mathrm{~ms}$ & $\begin{array}{c}\text { Internet access } \\
\text { service availability }\end{array}$ \\
\hline
\end{tabular}


The AIDER project was introduced for optimization of rescue management system with the main aim of reduction in road accidents. It is equipped with vehicles to detect post and precrashed situations. A specific box "black box" is used which holds different factors like terrain, speed, etc. to calculate all factors after and before accident happened. At the same time, it generates an automatic call to rescue center with the details which were assessed during and after accident. It helps in quick rescuing victims/injured [17]. Due to technological advancements, different intelligent transportation systems solutions have been introduced. The Japan, Europe and USA are on top in ITS technologies. In Europe, Smartway was developed, in Europe the, eSafety and in USA the Connected Vehicle Research (CVR) [18], [19], [20]. The prediction of road incidents duration is an important parameter in assisting the accident management system. In Korea, the Freeway Systems were introduced which can predict accident duration for large accident data set. Furthermore, the said model is helpful in mitigating congestion due to road accidents [21]. With the advancement in ITS technologies, the integration of new technologies in ITS is extremely important with the passage of time due to new environmental demands. A little deficiency may cause a huge lives loss, a huge waste of nonrenewable fossil energy, and degradation of quality of life, high pollution, pedestrians and vehicles. Three functionalities have been jointly integrated to manage safety and traffic. The functionalities are including the functionality of cognitive management is integrated in vehicle for exchanging traffic relevant information through knowledge inferring [22].

\subsection{Drone Technology/Unmanned Aerial Vehicle (UAV) and Applications}

Unmanned Aerial Vehicle (UAV) utilized by the logistics industry to provide transference of package, payload, food, drug, blood or other goods. A UAV based delivery allows quick delivery times, decrease response time, enhanced accuracy and decrease human cost and time. UAV makes the delivery service quicker and more convenient without human labor [23] [24]. In the recent trend, the market for delivery goods is high. The logistics industry introduces the UAV based delivery system for fast and efficient delivery. [25] [26] [27]. In previous eras, UAVs were only used for commercial, surveillance, military, police and other government agency's purpose, but UAVs is currently in use as children's toys, delivering payloads, crop monitoring [28] and spraying, mapping [29] [30], search \& rescue [31] [32], social coverage [33] etc.

In the field of medical, UAV plays a vital role to supply medicine, first aid kits, and different medical accessories of patient need and provide rescue service also [34] [35]. In the field of agriculture [28] [29] [30], UAVs used for automated planting, crop health monitoring, mine surveys, agriculture monitoring, groundwater discharge monitoring, plume tracking, air quality monitoring, avalanche patrols, wildlife surveys, forest inventory and fire mapping applications, monitoring of sport activity. Here, UAV survey delivers field data in less time to increase yields, provide assistive help of farmers and reduce costs, resources, etc. UAV technology has been used for observing forest along with the monitoring of deforestation, monitoring and assisting of highways. In addition, it is also being utilized in the field of transportation as payload delivery service in a professional way [36-41].

\section{Proposed Model}

\subsection{Proposed Model Description}

Figure 1 Model diagram has been described on details below.

\subsubsection{ITS Rescue Emergencies Services Center (IRESC)}

It is the core module of the proposed model. It controls all the activities such as receiving accident/emergency situation ubiquitously. After confirmation of accident, it provides an urgent first aid facility through UAV based on the received coordinates of the accident point. Along with this, for full medical assistance, it informs emergency services module to provide ambulances and police, etc.

\subsubsection{UAVs Based First Aid Services}

The UAVs Based First Aid Services module main responsibility is to get coordinates of the accident/demand point from ITS Rescue Emergencies Services Center (IRESC) to provide first aid medical services to seriously injured people. 


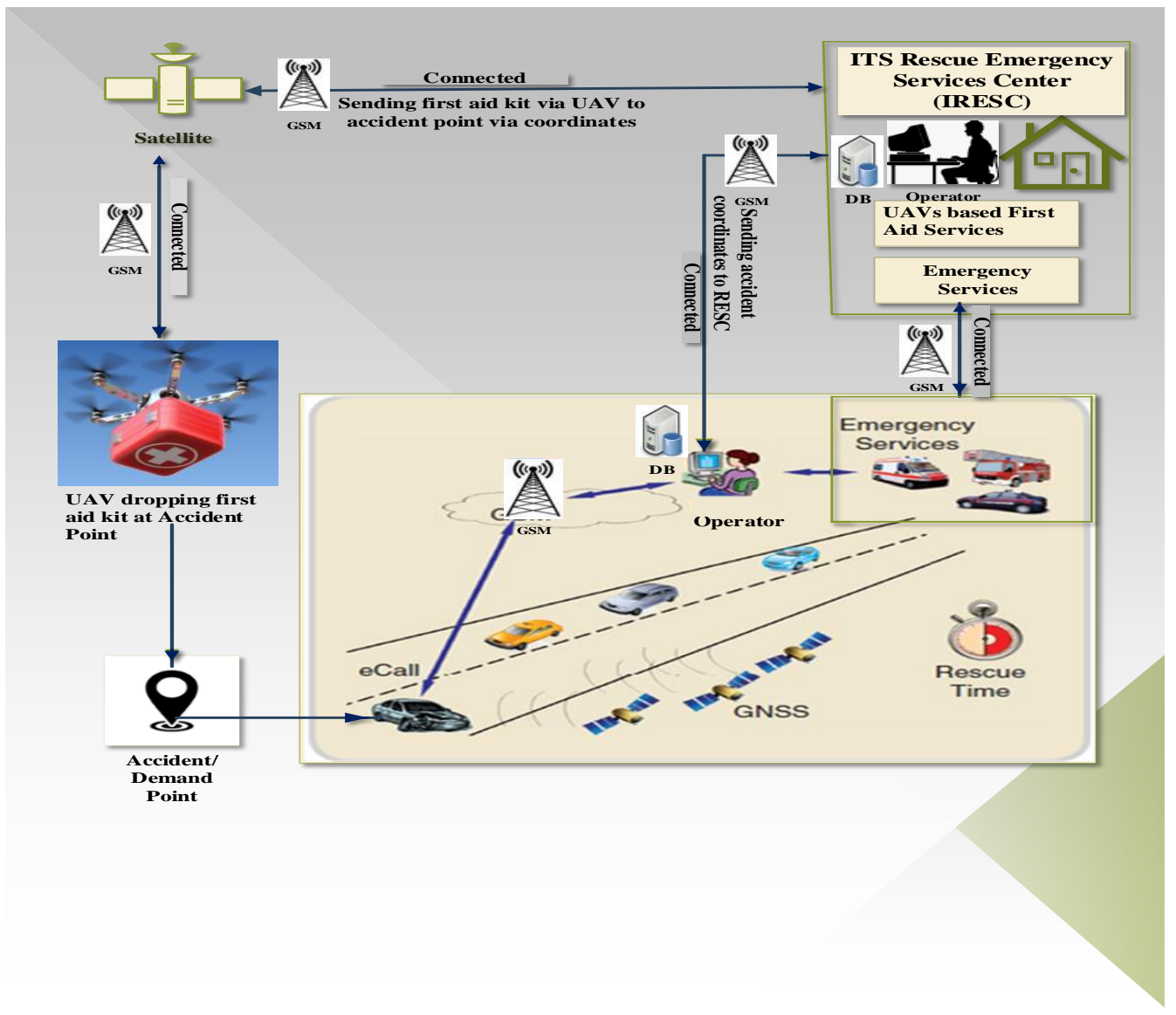

Figure 1: Model Diagram

\subsubsection{Emergency Services}

This module contains ambulance services and as well is connected with police department to assist accident/emergency situation in proper way. According to the coordinates received by IRESC, it reached the destination by following short root to assist victims appropriately.

\subsubsection{Unmanned Aerial Vehicle (UAV)}

The core component of the proposed framework is UAV which is used for the delivery of first aid medical assistance in emergency on urgent basis. It contains systems inclusive of meteorological events to obstacle avoidance, central control, Flight control system (FCS), emergency response system, weather response system, on-board GPS, gyroscope, accelerometer and barometer, payload dropping and payload dropping mechanism and flyaway protection system. It should be fully programmable and customizable flight platform which can be controlled remotely around in the distance of a range of more than $15 \mathrm{~km}$. UAV should have the capability and flexibility for the additional attachment of required components. During the flight, all relevant data (UAV details, mission details, and real-time data) should be shared with the ITS Rescue Emergencies Services Center (IRESC). Two TB48D batteries used which are connected in the parallel system.

\subsection{5. eCall}

It is security and in-vehicle safety system mainly used for assistance in on-road travel. Whenever, vehicles collide with 
some body or other vehicle then embedded sensors are automatically activated and generate an emergency voice call to the centralized database server of ITS Rescue Emergencies Services Center (IRESC). In addition, it also transmits the necessary information of accident with IRESC.

\subsubsection{Global Navigation Satellite System (GNSS)}

The short term used for Global Navigation Satellite System is GNSS. The main function of the proposed research model is to provide an autonomously geo-spatial position of the accident/emergency situation to IRESC for urgent assistance.

\subsubsection{Accident/Demand Point}

It is the actual accident/emergency area where accident happened and victims need to be assisted. Whenever accident happened, then through the eCall system embedded in the vehicles generates a call alert to the centralized database server. The centralized database server gets coordinates and proceeds rescue assistance process accordingly.

\subsubsection{Satellite}

Through the connected satellite, first aid medical assistance UAV can get coordinates of the accident area and handover the required kit to the emergency/demand point consequently. The centralized database server can feed coordinates and land UAV according to the demand in a ubiquitous mode.

\subsubsection{Centralized Database Server}

The centralized database server is maintained and controlled by IRESC operator. It maintains all information during road accident rescuing.

\subsubsection{Global System for Mobile (GSM)}

The Global System for Mobile communications stands for GSM. This standard describes protocols for mobile devices for second-generation $(2 \mathrm{G})$ digital cellular networks.

\section{Research Methodology}

In the proposed research work, the Delphi method has been used for validation. It is a quantitative research approach to collect expert opinions from different field experts about the proposed model through questionnaire. For final conclusion from the gathered experts' observations, the goodness of fit in chi-square test has been applied. The model is used to test hypotheses about the research model [42], [43].

\subsection{Survey Population}

For the validation and verification of the proposed model, around 60 participants were involved. The involved participants were selected based on professional accomplishments and technical awareness of the field. Table VI shows the characteristic of practitioner in which random sampling method was used for the selection of participants' panel.

Table VI:

\begin{tabular}{|c|c|c|c|c|c|c|c|c|}
\hline \multirow{2}{*}{$\begin{array}{l}\text { Category of } \\
\text { Responder }\end{array}$} & \multicolumn{2}{|c|}{ Gender } & \multirow[t]{2}{*}{ Age } & \multicolumn{3}{|c|}{ Academic Level } & \multirow{2}{*}{$\begin{array}{l}\text { Technology } \\
\text { User }\end{array}$} & \multirow{2}{*}{$\begin{array}{c}\text { Non-Technology } \\
\text { User }\end{array}$} \\
\hline & $\mathrm{M}$ & $\mathrm{F}$ & & $\begin{array}{c}\text { Under } \\
\text { Graduation }\end{array}$ & $\begin{array}{c}\text { Post- } \\
\text { Graduation }\end{array}$ & Master & & \\
\hline $\begin{array}{l}\text { UAVs Delivery } \\
\text { companies' } \\
\text { employees }\end{array}$ & 10 & 05 & $30-50$ & 9 & 6 & - & Yes & - \\
\hline $\begin{array}{c}\text { ITS } \\
\text { Departmental } \\
\text { Technologies } \\
\text { experts }\end{array}$ & 12 & 07 & $35-60$ & - & 11 & 08 & Yes & - \\
\hline $\begin{array}{l}\text { ITS Research } \\
\text { experts }\end{array}$ & 16 & 10 & $20-45$ & 08 & 13 & 05 & Yes & - \\
\hline Total & 38 & 22 & - & - & - & - & - & - \\
\hline
\end{tabular}




\subsection{Statement of the Hypotheses}

The proposed intended to inspect the impact of adopting UAV

in ITS, through the hypotheses shown in Table VII.

Table VII: Hypotheses Statement

\begin{tabular}{|c|c|}
\hline HYPOTHESES & STATEMENT \\
\hline \multirow[t]{2}{*}{1} & $\begin{array}{l}\mathrm{H}_{01} \text { : Proposed model is not reliable for the end user/rescue management authority. } \\
\mathrm{H}_{11} \text { : Proposed model is reliable for the end user/ rescue management authority. }\end{array}$ \\
\hline & $\begin{array}{l}\mathrm{H}_{01.1} \text { : Proposed model does not provide virtual visiting of the road accident area. } \\
\mathrm{H}_{11.1} \text { : Proposed model provides virtual visiting of the road accident area. }\end{array}$ \\
\hline \multirow[t]{2}{*}{2} & $\begin{array}{l}\mathrm{H}_{02}: \text { UAVs not provide quick service than traditional one. } \\
\mathrm{H}_{12}: \text { UAVs provides quick service than traditional one }\end{array}$ \\
\hline & $\begin{array}{l}\mathrm{H}_{02.1} \text { : Proposed model does not provide great assistive service to rescue management authority. } \\
\mathrm{H}_{12.1} \text { : Proposed model provides great assistive service to rescue management authority. }\end{array}$ \\
\hline \multirow[t]{2}{*}{3} & $\begin{array}{l}\mathrm{H}_{03} \text { : In proposed model, the rescue management authority cannot deliver first aid kit to the } \\
\text { accident/demand point. } \\
\mathrm{H}_{13} \text { : In proposed model, rescue management authority can deliver first aid kit to the accident/demand } \\
\text { point. }\end{array}$ \\
\hline & $\begin{array}{l}\mathrm{H}_{03.1}: \text { Proposed model does not provide facility to road accident management authority. } \\
\mathrm{H}_{13.1}: \text { Proposed model provides facility to road accident management authority. }\end{array}$ \\
\hline 4 & $\begin{array}{l}\mathrm{H}_{04} \text { UAV legislation, chance of stolen, mishandling of UAV navigation create hurdles during the } \\
\text { delivery process. } \\
\mathrm{H}_{14} \text { : UAV legislation, chance of stolen, mishandling of UAV navigation does not create hurdles during } \\
\text { the delivery process. }\end{array}$ \\
\hline 5 & $\begin{array}{l}\mathrm{H}_{05}: \text { Road accident management authority does not utilize control of UAV ubiquitously. } \\
\mathrm{H}_{15}: \text { Road accident management authority uses control of UAV ubiquitously. }\end{array}$ \\
\hline 6 & $\begin{array}{l}\mathrm{H}_{06} \text { : Proposed model does not save time for the road accident management authority. } \\
\mathrm{H}_{16} \text { : Proposed model saves time for the road accident management authority. }\end{array}$ \\
\hline 7 & $\begin{array}{l}\mathrm{H}_{07} \text { : Proposed model does not labor cost for UAV road accident management authority. } \\
\mathrm{H}_{17} \text { : Proposed model saves labor cost for UAV road accident management authority. }\end{array}$ \\
\hline 8 & $\begin{array}{l}\mathrm{H}_{08}: \text { Participants don't support the proposed system } \\
\mathrm{H}_{18} \text { : Participants supports the proposed system. }\end{array}$ \\
\hline 9 & $\begin{array}{l}\mathrm{H}_{09}: \text { Proposed model is not economically expensive. } \\
\mathrm{H}_{19}: \text { Proposed model is economically inexpensive. }\end{array}$ \\
\hline 10 & $\begin{array}{l}\mathrm{H}_{010} \text { : Road accident management authority don't satisfy from the proposed system } \\
\mathrm{H}_{110} \text { : Road accident management authority satisfies from the proposed system because it assists seriously } \\
\text { injured people during road accident on priority. }\end{array}$ \\
\hline
\end{tabular}

\subsection{Analyzing Factors}

This study presents results on ten tested null hypotheses. These hypotheses are tested on 0.05 level of significance using goodness-of-fit (Chi-square) test based on the above-mentioned hypotheses. The data is analyzed to check the efficiency and impact of the adopted features in the proposed model on the following observation factors which are shown in Table VIII. 
Table VIII:

\begin{tabular}{|l|l|}
\hline S.No & Analyzing Variable \\
\hline 1 & Reliability. \\
\hline 2 & Flexibility. \\
\hline 2 & Impact of service efficiency. \\
\hline 3 & Efficiency impact of Security. \\
\hline 4 & Ease-of-use. \\
\hline 5 & Efficiency impact of management authority time \& cost reduction. \\
\hline 6 & Efficiency impact of labor cost. \\
\hline 7 & Efficiency impact of traceability \& supports. \\
\hline 8 & Efficiency impact of implementation cost. \\
\hline 9 & Efficiency impact of management authority satisfaction. \\
\hline
\end{tabular}

\subsection{Reliability of the Proposed System}

RQ1: Proposed model is reliable for the end user/ rescue management authority.

Table-IX shows result of the chi-square test of goodness-of-fit shows that there is a significant difference in the frequencies at 0.05 level of significance $X^{2}(60,4)=15.833, p=.003$. Therefore, the first null hypothesis has been rejected.
RQ2: Proposed model provides virtual visiting of the road accident area

Table-X the result of the chi-square test of goodness-of-fit shows that there is a significant difference in the frequencies at 0.05 level of significance $X^{2}(60,4)=57.167, p=.000$.

Table IX: a. 0 cells (. $0 \%$ ) have expected frequencies less than 5. The minimum expected cell frequency is 12.0.

\begin{tabular}{|l|c|c|c|c|c|c|}
\hline & Observed N & Expected N & Residual & Chi-Square & df & Asymp. Sig. \\
\hline Strongly Agree & 19 & 12.0 & 7.0 & $15.833^{\mathrm{a}}$ & 4 & .003 \\
\hline Agree & 20 & 12.0 & 8.0 & & & \\
\hline Neutral & 6 & 12.0 & -6.0 & & & \\
\hline Disagree & 7 & 12.0 & -5.0 & & & \\
\hline Strongly Disagree & 8 & 12.0 & -4.0 & & & \\
\hline Total & 60 & & & & & \\
\hline
\end{tabular}

Table X: a. 0 cells $(0.0 \%)$ have expected frequencies less than 5 . The minimum expected cell frequency is 12.0.

\begin{tabular}{|l|c|c|c|c|c|c|}
\hline & Observed N & Expected N & Residual & Chi-Square & df & Asymp. Sig. \\
\hline Strongly Agree & 34 & 12.0 & 22.0 & $57.167^{\mathrm{a}}$ & 4 & .000 \\
\hline Agree & 14 & 12.0 & 2.0 & & & \\
\hline Neutral & 5 & 12.0 & -7.0 & & & \\
\hline Disagree & 2 & 12.0 & -10.0 & & & \\
\hline Strongly Disagree & 5 & 12.0 & -7.0 & & & \\
\hline Total & 60 & & & & & \\
\hline
\end{tabular}

RQ3: UAVs provides quick service than traditional one.

Table XI: The result of the applied test shows there is a hypothesis has been rejected significant difference in the frequencies at 0.05 level of 


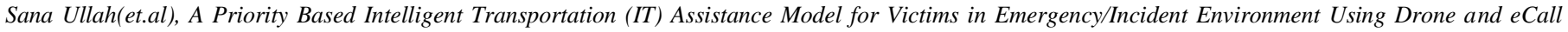

Table XI a. 0 cells $(.0 \%)$ have expected frequencies less than 5 . The minimum expected cell frequency is 12.0.

\begin{tabular}{|l|c|c|c|c|c|c|}
\hline & Observed N & Expected N & Residual & Chi-Square & df & Asymp. Sig. \\
\hline Strongly Agree & 18 & 12.0 & 6.0 & $12.500^{\mathrm{a}}$ & 4 & .014 \\
\hline Agree & 17 & 12.0 & 5.0 & & & \\
\hline Neutral & 14 & 12.0 & 2.0 & & & \\
\hline Disagree & 5 & 12.0 & -7.0 & & & \\
\hline Strongly Disagree & 6 & 12.0 & -6.0 & & & \\
\hline Total & 60 & & & & & \\
\hline
\end{tabular}

RQ4: Proposed model provides great assistive service to rescue management authority.

Table-XII: The result of the applied test shows that there is a significant difference in the frequencies at 0.05 level of significance $X^{2}(60,4)=50.800, p=.000$. Therefore, the null hypothesis has been rejected

RQ5: In proposed model, rescue management authority can deliver first aid kit to the accident/demand point.
Table XIII: The chi-square test statistics confirm that the number of participants who were agreed is significantly higher than those who were disagreed, $X^{2}(60,2)=12.100, p=.002$.

RQ 6: Proposed model provides facility to road accident management authority.

Table XIV: The result of this null hypothesis shows that there is a significant difference in the frequencies on 0.05 level of significance. $X^{2}(60,5)=67.600, p=.000$.

Table XII: a. 0 cells $(0.0 \%)$ have expected frequencies less than 5. The minimum expected cell frequency is 20.0

\begin{tabular}{|l|c|c|c|c|c|c|}
\hline & Observed N & Expected N & Residual & Chi-Square & df & Asymp. Sig. \\
\hline Yes & 46 & 20.0 & 26.0 & $50.800^{\mathrm{a}}$ & 2 & .000 \\
\hline No & 6 & 20.0 & -14.0 & & & \\
\hline I don't know & 8 & 20.0 & -12.0 & & & \\
\hline Total & 60 & & & & & \\
\hline
\end{tabular}

Table XIII: a. 0 cells (. $0 \%$ ) have expected frequencies less than 5 . The minimum expected cell frequency is 20.0 .

\begin{tabular}{|l|c|c|c|c|c|c|}
\hline & Observed N & Expected N & Residual & Chi-Square & df & Asymp. Sig. \\
\hline Yes & 31 & 20.0 & 11.0 & $12.100^{\mathrm{a}}$ & 2 & .002 \\
\hline No & 20 & 20.0 & .0 & & & \\
\hline I don't know & 9 & 20.0 & -11.0 & & & \\
\hline Total & 60 & & & & & \\
\hline
\end{tabular}

Table XIV: a. 0 cells $(0.0 \%)$ have expected frequencies less than 5. The minimum expected cell frequency is 20.0.

\begin{tabular}{|l|c|c|c|c|c|c|}
\hline & Observed N & Expected N & Residual & Chi-Square & df & Asymp. Sig. \\
\hline Yes & 50 & 20.0 & 30.0 & $67.600^{\mathrm{a}}$ & 2 & .000 \\
\hline No & 4 & 20.0 & -16.0 & 2 & & \\
\hline I don't know & 6 & 20.0 & -14.0 & & & \\
\hline Total & 60 & & & & & \\
\hline
\end{tabular}




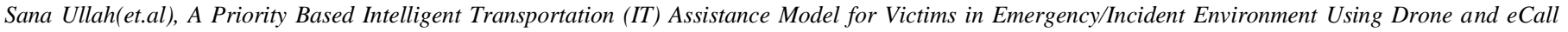
Technology,

(pp. $01-16)$

RQ7: UAV legislation, chance of stolen, mishandling of UAV navigation does not create hurdles during the delivery process.

Table XV: The statistics approve that the number of participants who were agreed is significantly higher than those who were disagreed, $X^{2}(60,2)=10.900, p=.002$. In this case, the null hypothesis has been rejected.

RQ8: Road accident management authority uses control of UAV ubiquitously.
Table XVI: The result of this null hypothesis show that there is a significant difference in the frequencies at 0.05 level of significance. $X^{2}(60,5)=48.600, p=000$.

RQ9: Proposed model saves time for the road accident management authority.

Table XVII: There is a significant difference in the frequencies at 0.05 level of significance $X^{2}(60,2)=14.700, p=.001$.

Table XV: a. 0 cells $(.0 \%)$ have expected frequencies less than 5. The minimum expected cell frequency is 20.0 .

\begin{tabular}{|l|c|c|c|c|c|c|}
\hline & Observed N & Expected N & Residual & Chi-Square & df & Asymp. Sig. \\
\hline Yes & 32 & 20.0 & 12.0 & $10.900^{\mathrm{a}}$ & 2 & .004 \\
\hline No & 13 & 20.0 & -7.0 & & & \\
\hline I don't know & 15 & 20.0 & -5.0 & & & \\
\hline Total & 60 & & & & \\
\hline
\end{tabular}

Table XVI: a. 0 cells (. $0 \%$ ) have expected frequencies less than 5. The minimum expected cell frequency is 10.0 .

\begin{tabular}{|c|c|c|c|c|c|c|}
\hline & Observed N & Expected N & Residual & Chi-Square & df & Asymp. Sig. \\
\hline Much more user friendly & 29 & 10.0 & 19.0 & $48.600^{\mathrm{a}}$ & 5 & .000 \\
\hline Not more or less user-friendly & 6 & 10.0 & -4.0 & & & \\
\hline Much less user-friendly & 12 & 10.0 & 2.0 & & & \\
\hline I don't know & 6 & 10.0 & -4.0 & & & \\
\hline Total & 60 & & & & & \\
\hline
\end{tabular}

Table XVII: a. 0 cells $(.0 \%)$ have expected frequencies less than 5 . The minimum expected cell frequency is 20.0.

\begin{tabular}{|l|c|c|c|c|c|c|}
\hline & Observed N & Expected N & Residual & Chi-Square & df & Asymp. Sig. \\
\hline Yes & 34 & 20.0 & 14.0 & $14.700^{\mathrm{a}}$ & 2 & .001 \\
\hline No & 13 & 20.0 & -7.0 & & & \\
\hline I don't know & 13 & 20.0 & -7.0 & & & \\
\hline Total & 60 & & & & & \\
\hline
\end{tabular}

RQ 10: Proposed model saves labor cost for UAV road accident management authority.

Table XVIII: The result shows that the number of participants who were agreed is significantly higher than those who were disagreed on said hypothesis, $X^{2}(60,4)=30.400, p=000$. Therefore, the seventh null hypothesis has been rejected.
RQ 16: Participants support the proposed system.

Table XIX: Result shows that the number of participants who were agreed is significantly higher than those who were disagreed in the said hypothesis. $\mathrm{X}^{2}(60,4)=32.500, p=000$. In this situation, the null hypothesis is rejected.

RQ 12: Proposed model is economically inexpensive. 


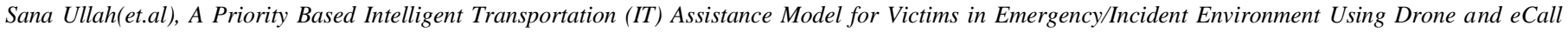
Technology,

(pp.01-16)

Table XX: There is a significant difference in the frequencies at 0.05 level of significance. $X^{2}(60,2)=36.400$, the $p=.000$.

RQ 13: Road accident management authority satisfies from the proposed system because it assists seriously injured people during road accident on priority.
Table XXI: shows there is a significant difference in the frequencies at 0.05 level of significance. $X^{2}(60,5)=42.167, p$ $=000$.

Table XVIII: a. 0 cells (. $0 \%$ ) have expected frequencies less than 5. The minimum expected cell frequency is 20.0 .

\begin{tabular}{|l|c|c|c|c|c|c|}
\hline & Observed N & Expected N & Residual & Chi-Square & df & Asymp. Sig. \\
\hline Yes & 40 & 20.0 & 20.0 & $30.400^{\mathrm{a}}$ & 2 & .000 \\
\hline No & 12 & 20.0 & -8.0 & & & \\
\hline I don't know & 8 & 20.0 & -12.0 & & & \\
\hline Total & 60 & & & & & \\
\hline
\end{tabular}

Table XIX: a. 0 cells (. $0 \%$ ) have expected frequencies less than 5. The minimum expected cell frequency is 20.0 .

\begin{tabular}{|l|c|c|c|c|c|c|}
\hline & Observed N & Expected N & Residual & Chi-Square & df & Asymp. Sig. \\
\hline Yes & 40 & 20.0 & 20.0 & $32.500^{\mathrm{a}}$ & 2 & .000 \\
\hline No & 5 & 20.0 & -15.0 & & & \\
\hline I don't know & 15 & 20.0 & -5.0 & & & \\
\hline Total & 60 & & & & & \\
\hline
\end{tabular}

Table XX: a. 0 cells $(.0 \%)$ have expected frequencies less than 5. The minimum expected cell frequency is 20.0 .

\begin{tabular}{|l|c|c|c|c|c|c|}
\hline & Observed N & Expected N & Residual & Chi-Square & df & Asymp. Sig. \\
\hline Yes & 42 & 20.0 & 22.0 & $36.400^{\mathrm{a}}$ & 2 & \\
\hline No & 8 & 20.0 & -12.0 & & & \\
\hline I don't know & 10 & 20.0 & -10.0 & & & \\
\hline Total & 60 & & & & & \\
\hline
\end{tabular}

Table XXI: a. 0 cells $(.0 \%)$ have expected frequencies less than 5 . The minimum expected cell frequency is 12.0

\begin{tabular}{|l|c|c|c|c|c|c|}
\hline & Observed N & Expected N & Residual & Chi-Square & df & Asymp. Sig. \\
\hline Strongly Agree & 32 & 12.0 & 20.0 & $42.167^{\mathrm{a}}$ & 4 & .000 \\
\hline Agree & 9 & 12.0 & -3.0 & & & \\
\hline Neutral & 7 & 12.0 & -5.0 & & \\
\hline Disagree & 6 & 12.0 & -6.0 & & \\
\hline Strongly Disagree & 6 & 12.0 & -6.0 & & \\
\hline$\quad$ Total & 60 & & & & \\
\hline
\end{tabular}

\subsection{Descriptive Statistics Discussion}

Table XXII associates all null hypothesis variables in single tabular. It collects all variables of null hypothesis and shows that the number of participants who were agreed is significantly higher than those who were disagreed in all hypothesis case. 


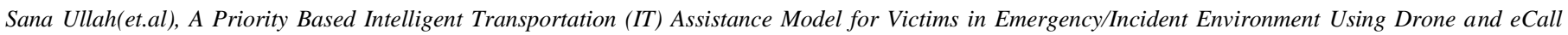

\begin{tabular}{|c|l|c|c|c|}
\multicolumn{1}{|c|}{ Table XXII: } & N & Mean & Std. Deviation \\
\hline S.No & \multicolumn{1}{|c|}{ Variable } & 60 & 2.40 & 1.278 \\
\hline 1 & Reliability. & 60 & 2.42 & 1.394 \\
\hline 2 & Flexibility. & 60 & 1.63 & 0.736 \\
\hline 2 & Impact of service efficiency. & 60 & 1.72 & 0.846 \\
\hline 3 & Efficiency impact of Security. & 60 & 2.78 & 1.941 \\
\hline 4 & Ease-of-use. & 60 & 1.65 & 0.820 \\
\hline 5 & $\begin{array}{l}\text { Efficiency impact of road accident management authority time \& } \\
\text { cost reduction. }\end{array}$ & 60 & 1.47 & 0.724 \\
\hline 6 & Efficiency impact of labor cost. & 60 & 1.58 & 0.869 \\
\hline 7 & Efficiency impact of tractability \& supports. & 60 & 1.47 & 0.769 \\
\hline 8 & Efficiency impact of implementation cost. & 60 & 2.08 & 1.406 \\
\hline
\end{tabular}

The analyzing of overall results shows that reliability and flexibility have a maximum mass of agreement from participants respectively which are shown in the table XXIII.

Table XXIII:

\begin{tabular}{|c|c|c|c|c|}
\hline Hypotheses & $\alpha$ & P-value & $\begin{array}{c}\text { Null } \\
\text { Hypotheses }\end{array}$ & Conclusion \\
\hline RQ-1 & \multirow{13}{*}{$\stackrel{n}{0}$} & .003 & \multirow{13}{*}{$\begin{array}{l}\vec{D} \\
\frac{d}{\mathscr{U}} \\
\stackrel{\mathscr{Q}}{ }\end{array}$} & $\begin{array}{l}\text { Proposed UAV based first aid kit delivery model is reliable for the road } \\
\text { accident management authority. }\end{array}$ \\
\hline RQ-2 & & .000 & & Proposed model provides virtual visiting of accident/demand point. \\
\hline RQ-3 & & .014 & & $\begin{array}{l}\text { UAV based delivery service faster, safer and more cost-effective than } \\
\text { traditional one. }\end{array}$ \\
\hline RQ-4 & & .000 & & $\begin{array}{c}\text { Proposed model provides great assistive service to visit accident/demand } \\
\text { point. }\end{array}$ \\
\hline RQ-5 & & .002 & & $\begin{array}{l}\text { In proposed model, road accident management authority can deliver first aid } \\
\text { kit to accident/demand point. }\end{array}$ \\
\hline RQ-6 & & .000 & & Proposed model provides facility to road accident management authority \\
\hline RQ-7 & & 0.004 & & $\begin{array}{l}\text { UAV legislation, chance of stolen, mishandling of UAV navigation not create } \\
\text { hurdles during the delivery process. }\end{array}$ \\
\hline RQ-8 & & .000 & & Road accident management authority controls the UAV ubiquitously. \\
\hline RQ-9 & & .001 & & Proposed model saves time for the road accident management authority. \\
\hline RQ-10 & & .000 & & $\begin{array}{l}\text { Proposed model saves time and labor cost for UAV based first kit delivery in } \\
\text { road accident management authority. }\end{array}$ \\
\hline RQ-11 & & .000 & & $\begin{array}{c}\text { Participants support the proposed UAV based delivery system for road } \\
\text { accident management. }\end{array}$ \\
\hline RQ-12 & & .000 & & Proposed model is economically inexpensive. \\
\hline RQ-13 & & .000 & & $\begin{array}{l}\text { Road accident management authority is satisfied from the proposed system } \\
\text { because it provides UAV based first kit delivery in road accident on priority } \\
\text { based in emergency. }\end{array}$ \\
\hline
\end{tabular}


Table XXIII represents a summary of the results of the all null hypotheses. The table shows all null hypotheses are rejected at the 0.05 level of significance.

\section{Conclusion}

Different research projects have worked on accident/emergency situations to assist properly. In the proposed drone technology and eCall technology to assist seriously injured in road accident in intelligent transportation system (ITS). In the first emergency situation, first aid kit or needed medical assistance are provided to more needed injured to whom urgent medical assistance is required on priority basis through drone technology. In the second phase, proper ambulance and other services are provided. The main aim of the model is to provide on time medical assistance to road accident injured whose lives can be lost with a little bit delay in urgent medical assistance. Furthermore, the other advantages of the proposed model are including to diminished/minimized lives losses, saving time, speed up rescuing process; maximize efficiency, improving the transport results like traffic resilience, travel reliability, environment protection and road safety.

\section{ACKNOWLEDGMENT}

I must express my gratitude to my wife, for her continued support and encouragement. I would also like to express my wholehearted thanks to my family for their generous support they provided me throughout my life and particularly through the process of my educational career.

\section{REFERENCES}

[1] John Njord and Dr. Joseph Peters, ITS Handbook Japan, 2002-2003 [Online]. Available: http://www.mlit.go.jp/road/ITS/index/indexHBook.html.

[2] Qureshi, Kashif Naseer, and Abdul Hanan Abdullah. "A survey on intelligent transportation systems." Middle-East Journal of Scientific Research 15.5 (2013): 629-642.

[3] Sorensen, J., 2012. Review of Existing Literature and Deployment Tracking Surveys Decision Factors Influencing ITS Adoption.

[4] Dr. j, shibata, sumitomo electric industries Ltd and R. French, R \& D French Associates, "Progress in intelligent transportation systems in the US, Europe and Japan" ISATA magazine, pag. 27-29, 1999.

[5] Shladover, S., "Review of the state of development of advanced vehicles control systems (AVCS)", Vehicle system dynamics, 1995.
[6] "Advanced Rural Transportation systems strategic plan", U.S. Department of transportation, 1998, (http://www.itsa.org)

[7] Peng, Y., Zhang, Y., Tang, Y. and Li, S., 2011. An incident information management framework based on data integration, data mining, and multi-criteria decision making. Decision Support Systems, 51(2), pp.316-327.

[8] Kim, J.K., Sharman, R., Rao, H.R. and Upadhyaya, S., 2007. Efficiency of critical incident management systems: Instrument development and validation. Decision Support Systems, 44(1), pp.235-250.

[9] Wang, Y., et al., 2012. Perceptual control architecture for cyber-physical systems in traffic incident management. Journal of Systems Architecture,

[10] Shah, S.A.A., Kim, H., Baek, S., Chang, H. and Ahn, B.H., 2008. System architecture of a decision support system for freeway incident management in Republic of Korea. Transportation Research Part A: Policy and Practice, 42(5), pp.799-810.

[11] Choi, E.H.C., Taib, R., Shi, Y. and Chen, F., 2007. Multimodal user interface for traffic incident management in control room. IET Intelligent Transport Systems, 1(1), pp.27-36.

[12] Haddow, G., J. Bullock and D.P. Coppola, Introduction to emergency management. 2010: Butterworth-Heinemann.

[13] Lambert, J.H., Parlak, A.I., Zhou, Q., Miller, J.S., Fontaine, M.D., Guterbock, T.M., Clements, J.L. and Thekdi, S.A., 2013. Understanding and managing disaster evacuation on a transportation network. Accident Analysis \& Prevention, 50, pp.645-658.

[14] Yoon, S.W., Velasquez, J.D., Partridge, B.K. and Nof, S.Y., 2008. Transportation security decision support system for emergency response: A training prototype. Decision Support Systems, 46(1), pp.139-148.

[15] 16. Chunlin, D. and Y. Liu, 2012. Sample Average Approximation Method for Chance Constrained Stochastic Programming in Transportation Model of Emergency Management. Systems Engineering Procedia, 5: 137-143.

[16] Buchenscheit, A., Schaub, F., Kargl, F. and Weber, M., 2009, October. A VANET-based emergency vehicle warning system. In Vehicular Networking Conference (VNC), 2009 IEEE (pp. 1-8). IEEE.

[17] An, S. H., Lee, B. H., \& Shin, D. R. (2011, July). A Survey of Intelligent Transportation Systems. In Computational Intelligence, Communication Systems and Networks (CICSyN), 2011 Third International Conference on (pp. 332-337). IEEE

[18] Abdalla, G. M., Abu-Rgheff, M. A., \& Senouci, S. M. (2007). Current trends in vehicular ad hoc networks. Ubiquitous Computing and Communication Journal, 1-9.

[19] Xiong, Z., Sheng, H., Rong, W., \& Cooper, D. E. (2012). Intelligent transportation systems for smart cities: a 
progress review. Science China Information Sciences, 55(12), 2908-2914.

[20] Chung, Y. (2010). Development of an accident duration prediction model on the Korean Freeway Systems. Accident Analysis \& Prevention, 42(1), 282-289.

[21] Dimitrakopoulos, George, and Panagiotis Demestichas. "Intelligent transportation systems." IEEE Vehicular Technology Magazine 5.1 (2010): 77-84.

[23]. Papadimitratos, P., De La Fortelle, A., Evenssen, K., Brignolo, R. and Cosenza, S., 2009. Vehicular communication systems: Enabling technologies, applications, and future outlook on intelligent transportation. IEEE communications magazine, 47(11).

[24] Khan, M. A., Alvi, B. A., Safi, A., \& Khan, I. U. Drones for Good in Smart Cities: A Review.

[25] Karcz, J., \&Ślusarczyk, B. (2016). IMPROVEMENTS IN THE QUALITY OF COURIER DELIVERY. International Journal for Quality Research, 10(2).

[26]. Brar, S., Rabbat.,R,Raithatha, V, Runcie,G., Yu, A (2015). Sutardja Center for Entrepreneurship Technology Technical Report; Drones for Deliveries.[Accessed November 2018] http://scet.berkeley.edu/wpcontent/uploads/ConnCarProjectReport-1.pdf.

[27] Bisht,.S (2017). Drone Delivery, Evolution in the field of Logistics Industry. [Accessed] https://www.shiprocket.in/blog/drone-delivery-evolutionin-the-field-of-logistics-industry/ https://www.amazon.com/Amazon-PrimeAir $/ \mathrm{b} ? \mathrm{ie}=\mathrm{UTF} 8 \&$ node $=8037720011$

[29] Giles, D. K., \& Billing, R. C. (2015). Deployment and Performance of a UAV for Crop Spraying. Chemical Engineering Transactions, 44.

[30] Faiçal, B. S., Pessin, G., Geraldo Filho, P. R., Carvalho, A. C., Furquim, G., \&Ueyama, J. (2014, November). Finetuning of UAV control rules for spraying pesticides on crop fields. In Tools with Artificial Intelligence (ICTAI), 2014 IEEE 26th International Conference on (pp. 527-533). IEEE.

[31] van Vark, C (2015) 'Drones set to give global farming a makeover', Guardian, 26 December

[32] Mathers, I (2014) 'View on Migration: Drone Searches Aid Refugee Rescues', SciDev.Net, 11 December
[33] Yeong, S. P., King, L. M., \&Dol, S. S. (2015). A review on marine search and rescue operations using unmanned aerial vehicles. Int. J. Mech. Aerosp. Ind. Mech. Manuf. Eng, 9(2), 396-399.

[34]Thorpe, H. (2017). Action sports, social media, and new technologies: Towards a research agenda. Communication \& sport, 5(5), 554-578.

[35] Thiels, C. A., Aho, J. M., Zietlow, S. P., \& Jenkins, D. H. (2015). Use of unmanned aerial vehicles for medical product transport. Air medical journal, 34(2), 104-108.

[36] Linchant, J., Lisein, J., Semeki, J., Lejeune, P., \&Vermeulen, C. (2015). Are unmanned aircraft systems (UAS s) the future of wildlife monitoring? A review of accomplishments and challenges. Mammal Review, 45(4), 239252.

[37] Gonzalez, L. F., Montes, G. A., Puig, E., Johnson, S. Mengersen, K., \& Gaston, K. J. (2016). Unmanned Aerial Vehicles (UAVs) and artificial intelligence revolutionizing wildlife monitoring and conservation. Sensors, 16(1), 97.

[38] Wallace, L., Musk, R., \&Lucieer, A. (2014). An assessment of the repeatability of automatic forest inventory metrics derived from UAV-borne laser scanning data. IEEE Transactions on Geoscience and Remote Sensing, 52(11), $7160-7169$

[39] Ollero, A., \& Merino, L. (2006). Unmanned aerial vehicles as tools for forest-fire fighting. Forest Ecology and Management, 234(1), S263.

[40] Merino, L., Caballero, F., Martínez-De-Dios, J. R., Maza, I., \&Ollero, A. (2012). An unmanned aircraft system for automatic forest fire monitoring and measurement. Journal of Intelligent \& Robotic Systems, 65(1-4), 533-548.

[41] Kumar, G. D., Jeeva, B. (2017). Drone Ambulance for Outdoor Sports. Asian Journal of Applied Science and Technology (AJAST), 1(5), 44-49.

[42] Sackman, H. (1974). Delphi assessment: Expert opinion, forecasting, and group process (No.RAND R-1283-PR). RAND CORP SANTA MONICA CA.

[43] Okoli, C., \&Pawlowski, S. D. (2004). The Delphi method as a research tool: an example, design considerations and applications. Information \& management, 42(1), 15-29. 